Brit. F. vener. Dis. (1968), 44, 232.

\title{
"T" STRAIN MYCOPLASMA IN THE FEMALE URO-GENITAL TRACT*
}

\author{
BY \\ J. F. ARCHER \\ Department of Medical Microbiology, University of Sheffield
}

There is at present little agreement about the significance of the " $T$ " strain mycoplasma in genito-urinary infections. Workers who have studied the problem have expressed opinions which vary from its confident indictment as a cause of "nonspecific urethritis" to its dismissal as simple evidence of promiscuity or as completely irrelevant.

Shepard (1956) and Shepard, Lunceford, and Campbell (1964) suggested that " $T$ " strain mycoplasma may be an aetiological agent in nongonococcal urethritis. This view seems to be supported by findings of Csonka, Williams, and Corse (1966), who isolated this organism from 70 per cent. of males with non-specific urethritis, but from only 13 per cent. of normal males; these workers also isolated the organism from urine in 65 per cent. of a group of pregnant women. The opposite view was put forward by Ingham, Macfarlane, Hale, Selkon, and Codd (1966), who looked for " $T$ " strain mycoplasma in males with acute gonorrhoea and with non-specific urethritis and in normal controls, and failed to show any statistically significant difference between the findings in the three groups.

These variations may be due to differences in cultural techniques or, as Ingham and others (1966) suggested, to differences in age or social class between the patients and controls.

Shepard (1966) suggested that the prevalence of " $T$ " strain mycoplasma in the female genital tract may be related to the frequency of sexual intercourse. The present study was undertaken to see if this was so.

\section{Material}

Single specimens of urine from about 100 women in each of the following groups were examined for "T" strain mycoplasma.

\footnotetext{
* Received for publication March 2, 1968.
}

Group I Pregnant females attending antenatal clinics for routine examination, having neither vaginal discharge nor genitourinary abnormality (100).

Group II Married nulliparous females attending infertility clinics (94).

Group III Elderly female geriatric in-patients (98).

Group IV A group of nuns and novices of an enclosed order (105).

The subjects in Groups I, II, and IV were all aged between 18 and 30 years and the ages in Group III ranged from 65 to 80 years.

\section{Collection of Specimens}

A preliminary investigation showed that vaginal swabs had no advantage over "unclean" specimens of urine for the isolation of " $T$ " strain mycoplasma.

At least $200 \mathrm{ml}$. urine were collected in a sterile wide-necked bottle without any perineal toilet and without any attempt at preventing contamination from the labia. All specimens were cultured within 5 hours of voiding and no attempt was made to refrigerate the specimens between collection and culture.

\section{Culture}

$200 \mathrm{ml}$. volumes of urine were centrifuged at 10,000 r.p.m. $(23,000 \mathrm{G})$ at $0^{\circ} \mathrm{C}$. for 30 minutes and a standard loopful of the deposit was inoculated on to Shepard's PPLO medium. This consisted of:

Trypticase soy broth

(Baltimore Biological Labs*)

"Ionagar" No. 2 (Oxoid Ltd $\dagger$ )

Horse Serum (Oxoid Ltd)

Penicillin

3. 0 per cent. $1 \cdot 13$ per cent. $10 \cdot 0$ per cent. 1,000 units $/ \mathrm{ml}$.

The trypticase soy broth and Ionagar No. 2 were sterilized by autoclaving at $120^{\circ} \mathrm{C}$. for 15 minutes and allowed to cool to $50^{\circ} \mathrm{C}$. before the penicillin and horse serum were added.

Before the addition of serum the $\mathrm{pH}$ was adjusted to 6 . The final $\mathrm{pH}$ of the medium was 6 .

* Baltimore Biological Laboratories, Baltimore, Maryland. † Oxoid Ltd, London. 
After inoculation the culture plates were incubated in an atmosphere of 10 per cent. $\mathrm{CO}_{2}$ and 90 per cent. $\mathrm{N}_{2}$ at $37^{\circ} \mathrm{C}$. They were examined at 48 and $96 \mathrm{hrs}$ using a plate microscope $(\times 100)$. The amount of growth on each primary plate was assessed as heavy $(+++)$, medium $(++)$, or scanty $(t)$, according to the number of colonies. In addition, a standard loopful of the urinary deposit was inoculated into a PPLO broth containing the same supplements and, after 18 hrs' incubation, these broths were subcultured on solid PPLO medium. After comparing fifty such parallel cultures it was found that prior incubation in broth gave no more positive results than primary culture, so the remaining specimens were examined by the simpler direct plating method. Colonies of " $T$ " strain mycoplasma were identified by their typical morphology and by their failure to increase in size with incubation beyond $48 \mathrm{hrs}$. In addition, all isolates were tested by the method of Purcell, Taylor-Robinson, Wong, and Chanock (1966) and found to possess urease activity. Random strains were tested by the growth inhibition method of Stanbridge and Hayflick (1967) using specific "T" strain antiserum (Robbin Labs*); the growth of all strains so tested was inhibited.

\section{Results}

The frequencies of isolation of " $T$ " strain mycoplasma from the specimens of urine are shown in the Table.

TABLE

ISOLATION OF “T” STRAIN MYCOPLASMA FROM 4 GROUPS OF WOMEN

\begin{tabular}{|c|c|c|c|c|}
\hline \multirow{2}{*}{ Group } & \multirow{2}{*}{$\begin{array}{c}\text { Total } \\
\text { No. } \\
\text { Examined }\end{array}$} & \multicolumn{3}{|c|}{ " $T$ " Strain Mycoplasma Isolations } \\
\hline & & $\begin{array}{c}\text { No. } \\
\text { Infected }\end{array}$ & $\begin{array}{l}\text { Amount of } \\
\text { Growth }\end{array}$ & Percentage \\
\hline $\begin{array}{l}\text { I Antenatal } \\
\text { Clinic }\end{array}$ & 100 & 58 & $\begin{array}{r}+++25 \\
++17 \\
+\quad 16\end{array}$ & 58 \\
\hline $\begin{array}{l}\text { II Infertility } \\
\text { Clinic }\end{array}$ & 94 & 48 & 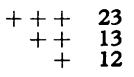 & 51 \\
\hline $\begin{array}{l}\text { III Geriatric } \\
\text { Hospital }\end{array}$ & 98 & 28 & $\begin{array}{rr}+++ & 17 \\
++ & 6 \\
+ & 5\end{array}$ & $28 \cdot 5$ \\
\hline IV Nuns & 105 & 8 & $\begin{array}{rr}+++ & 3 \\
+ & 3 \\
+ & 2\end{array}$ & $7 \cdot 6$ \\
\hline
\end{tabular}

\section{Discussion}

" $T$ " strain mycoplasmata were isolated from 58 per cent. of 100 patients attending antenatal clinics and from 51 per cent. of 94 patients attending "infertility" clinics. In contrast they were isolated from 28.5 per cent. of elderly patients in a geriatric unit and from only $7 \cdot 6$ per cent. of nuns in a convent.

* Robbin Laboratories Inc., Chapel Hill, North Carolina, U.S.A.
The results obtained from the culture of urines from pregnant women are similar to those reported by previous workers. The organism was isolated from the genital tract in over half the healthy young married women examined, whether pregnant or not. This suggests that the organism may be a commensal, that women may act as asymptomatic carriers, and that the possibility of their consorts becoming infected must be high. The very low isolation rate obtained with urines from nuns indicates that sexual intercourse must be seriously considered as a factor in the establishment and persistence of these organisms in the female genital tract. It has been suggested (Csonka and others, 1966) that pathogenic and non-pathogenic forms of the organism may exist. Another suggestion is that the virulence of a particular strain may be enhanced either by the presence of other organisms or by alterations in local conditions in the genital tract, such as trauma or the presence of seminal fluid. This situation would be similar to that observed with Trichomonas vaginalis and the same pattern of re-infection between sexual partners ("ping-pong" infection) may apply.

A survey is being conducted to see whether there is any correlation between the incidence of $T$. vaginalis and that of " $T$ " strain mycoplasma in similar groups.

The role of " $T$ " strain mycoplasma in the pathogenesis of human disease remains obscure, but recent observations on the epidemiology of carcinoma of the cervix may perhaps be relevant. Martin (1967) discussed the relation of carcinoma of the cervix to such factors as early marriage and multiple sexual partners, and indicated that the disease has features in common with known venereal types of communicable disease. If, as seems possible, there is a factor transmitted during coitus which contributes to the subsequent development of carcinoma of the cervix, then the role of " $T$ " strain mycoplasma should be considered.

\section{Summary}

The presence of " $T$ " strain mycoplasma was ascertained by culture of the urine of 100 pregnant women, 94 women attending an infertility clinic, 98 women in a geriatric unit, and 105 nuns of an enclosed order, and was found to be present in $58,51,29$, and 8 per cent. respectively. The implications of these findings are discussed in relation to sexual activity, venereal infection, and the pathogenesis of human disease such as cervical carcinoma. 
I am indebted to Prof. C. P. Beattie for his assistance in the planning of this investigation and should like to thank many colleagues for their advice in the preparation of this paper.

\section{REFERENCES}

Csonka, G. W., Williams, R. E. O., and Corse, J. (1966). Lancet, 1, 1292.

Ingham, H. R., MacFarlane, W. V., Hale, J. R., Selkon, J. B., and Codd, A. A. (1966). Brit. F. vener. Dis., 42, 269.

Martin, C. E. (1967). Amer. F. publ. Hlth, 57, 803.

Purcell, R. H., Taylor-Robinson, D., Wong, D., and Chanock, R. M. (1966). F. Bact., 92, 6.

Shepard, M. C. (1956). Ibid., 71, 362.

- (1966). Hlth Lab. Sci., 3, 163.
, Alexander, C. E., Lunceford, C. D., and Campbell, P. E. (1964). Ұ. Amer. med. Ass., 188, 729.

Stanbridge, E. and Hayflick, L. (1967).F. Bact., 93, 1392.

La souche " $T$ " des mycoplasmes dans les voies uro-génitales de la femme

RÉsumé

La présence de la souche " $T$ " des mycoplasmes a été constatée par culture de l'urine de 100 femmes enceintes, de 94 femmes visitant un dispensaire d'infécondité, de 98 femmes d'une salle gériatrique et de 105 religieuses d'un ordre cloîtré, et cette souche a été trouvée dans $58,51,29$, et 8 pour cent respectivement. Les implications de ces constatations sont discutées en relation de l'activité sexuelle, de l'infection vénérienne et de la pathogénèse d'une maladie humaine, telle que le cancer du col. 